\title{
Contribution of Principal Leadership, Motivation and Work Environment to The Achievement of Teachers of SDN Se Gugus Alalak District of North Banjarmasin
}

\author{
DEASY NATHALIA
}

Thesis Master of Education Management Program, Postgraduate Program, Lambung Mangkurat University Banjarmasin,

\begin{tabular}{|c|c|}
\hline ARTICLE INFO & A B S T R A C T \\
\hline \multirow[t]{2}{*}{$\begin{array}{l}\text { Article history: } \\
\text { Received: June } \\
\text { Revised; August } \\
\text { Accepted: September } \\
\text { Keywords: Principal Lead- } \\
\text { ership, Work Motivation, } \\
\text { Work Environment, } \\
\text { Teacher Work Achieve- } \\
\text { ment }\end{array}$} & $\begin{array}{l}\text { The purpose of this study was to describe: (I) the amount of contribution of the } \\
\text { principal's leadership on the achievment of Public Elementary School Teachers in } \\
\text { Alalak Cluster, North Banjarmasin Subdistrict; (2) the amount of contribution of } \\
\text { Teacher work motivation on the work achievment of Public Elementary School } \\
\text { Teachers in Alalak Cluster, North Banjarmasin Subdistrict (3) the amount of con- } \\
\text { tribution of the teacher's work environment on the work achievment Public Ele- } \\
\text { mentary School Teachers in Alalak Cluster, North Banjarmasin Subdistrict; (4) the } \\
\text { amount of contribution of the principals' leadership, motivation and work envi- } \\
\text { ronment simultaneously on the work performance of Public Elementary School } \\
\text { Teachers in Alalak Cluster, North Banjarmasin Subdistrict } \\
\text { The study uses a quantitative approach with descriptive and linear regression analy- } \\
\text { sis. The population in this study were all elementary school teachers in the Alalak } \\
\text { Cluster in North Banjarmasin Subdistrict. The sample used was I04 teachers. Data } \\
\text { collection techniques used were questionnaire and observation techniques. While } \\
\text { the data analysis technique uses statistical tests, regression analysis and F test. } \\
\text { The results showed that: (I) Principal leadership made an effective contribution of } \\
31,5 \% \text { on teacher work achievment, (2) Work motivation provided an effective } \\
\text { contribution of } 40 \% \text { on the work achievment of teachers in SDN North Banjar- } \\
\text { masin Subdistrict, (3) Teacher's work environment made an effective contribution } \\
\text { of } 34,4 \% \text {, on the work achievment of teachers in Public Elementary School in } \\
\text { North Banjarmasin Subdistrict (4) Principal leadership, Motivation of teacher } \\
\text { work and Teacher's work environment simultaneously contributed } 50 \% \text { to the } \\
\text { work achievment of Public Elementary School Teachers in Alalak Cluster, North } \\
\text { Banjarmasin Subdistrict } \\
\text { It is recommended to parties involved in the world of education such as principals, } \\
\text { teachers, supervisors, heads of office, should always improve the quality of their } \\
\text { work performance so that educational goals can be achieved easily. }\end{array}$ \\
\hline & $\begin{array}{l}\text { (C) O } 2019 \text { The Authors. Journal of K6, Education, and Management (j- } \\
\text { K6EM). ISSN: 2580-2135. Published by Graduated Program of Educa- } \\
\text { tional Management, Universitas Lambung Mangkurat, Banjarmasin } \\
\text { 70123, Indonesia. This is an open access article under the CC-BY-SA license. }\end{array}$ \\
\hline
\end{tabular}

*Correspondence:Deasy Nathalia, Email:deasyn2312@gmail.com 


\section{Introduction}

In order to improve the quality of education through improving the quality and work performance of teachers determined in Article 39 of Law No. 20/2003 concerning lesson planning, teaching implementation, evaluating learning outcomes, coaching, training, conducting research, and doing community service. This is a challenge for teachers to determine the learning process.

One indicator of quality of human is having high work performance. This work achievement is very needed by various government institutions as well as private sectors. Employees or workers who have high work performance will always be aware of their respective responsibilities and finish the task given based on their own ability to get maximum work results. Meanwhile, most of the employees who do not have work performance will only give negative results for the employees themselves and the institution. Improving the work performance of teachers it is very necessary to do both individuals and groups in order to improve better work outcomes. As expressed by Handoko (2007: 135), work performance is an achievement that is reached by organization to evaluate the employees.

\section{School Leadership}

Wahjosumidjo (2013: 83) states that the principal is a functional teacher who is assigned to lead the school which regulates the teaching and learning process, or the place where there is interaction between the teacher who gives lessons and learners that receive lessons. Effective headmaster leadership will influence the participation of the staff to do what is their responsibility with feeling satisfied. They can work in accordance with the context of being able to provide a vision, set clear goals and supported by all together, monitoring and analyzing achievement, moreover being able to improve the achievement by giving direction and guidance, training and guiding.

The success of education in schools is largely determined by the success of the principal in the management of educational staffs who are available at the school. The principal is responsible for organizing educational activities, school administration, fostering other education staff, and utilizing and maintaining facilities and also infrastructure.

A person's work performance needs to be studied in relation to the implementation of a job that provides an understanding of work or someone's work that can be directly or indirectly carried out by others (Nawawi, 2005: 234). Therefore the principal's leadership, work motivation and the work environment influence the teacher's work performance.

According to Wahjosumidjo, in organizational practice, the word "lead" uses the connotation of moving, guiding, protecting, fostering, providing role models, encouraging, providing assistance, and so on (2005: 13). Leadership is an activity of individuals who lead the activities of a group towards a common goal (Hemphill \& Coons, 1957). Whereas according to Munir (2008: 32), can be concluded that leadership is the ability or attitude of someone to move, foster, give encouragement to subordinates to achieve specified goals.

Wahjosumidjo means that: "Principals are functional personnel who are obliged to lead schools where teaching and learning processes are held, or places where interactions occur between teachers who teach and learners who receive lessons". The principal is described as someone who has high expectations for the staff and students. The principal is those who better understand their tasks and those who determine the rhythm for their school. This formula shows the importance of school principals in moving school life to achieve goals. Successful principals are principals who succeed in understanding schools as unique complex organizations, and are able to assist their role in leading schools. Principals who is able to carry out his duties and obligations can be said to be a good school principal, So thus, it is clear the principal as a leader must carry out his duties, besides the duty of the principal to lead and managing the school, principal is also required to be able to create a conducive atmosphere in the work environment.

\section{Motivation}

Robbins and Judge (2007: 56) define motivation as a process that explains the intensity, direction and perseverance of an individual to achieve his goals. Wibowo (2010: 379) mentions motivation is a drive to a series of processes of human behavior in achieving goals, while the elements contained in motivation include elements of generating, directing, maintaining, showing intensity, being continuous and having goals.

\section{Work Environment}

The work environment in a company is very important for management to pay attention. Although the work environment does not carry out the production process in a company, but the work environment has direct influence on the employees who carry out the production process. Work environment is an atmos- 
phere where employees carry out activities every day. A conducive work environment provides a sense of security and allows employees to work optimally. If employees do not have a comfortable environment, the employee's work results must also not be optimal.

According to Simanjuntak (2003: 39) the work environment can be interpreted as a whole tool device that is faced, the surrounding environment where a person works, the method of work, as the effect of his work both as individuals and as a group. Whereas according to Mardiana (2005: 78) work environment is an environment where employees do their daily work. Furthermore, Bambang (2000: 122) states the work environment is one of the factors that affect the performance of an employee. An employee who works in a work environment that supports him to work optimally will produce good performance. Conversely, if an employee works in an inadequate work environment and does not support to work optimally it will make the employee concerned become lazy, tired quickly so that achievement of these employees will be low.

\section{Teacherwork Performance}

Work performance is the result of the work of an employee for a certain period compared to various possibilities such as standards, targets / goals or criteria that have been determined in advance and agreed upon together. According to Hasibuan (2008: 64) states that "Job performance is a result of work achieved by someone in carrying out the tasks assigned to him based on skills, experience, and sincerity and time.

The research is expected to provide input to principals, teachers, stakeholders, students and other elements related to education. to empower the potential of the school, in order to increase teacher development in schools, especially input to teachers to always increase work motivation, foster a positive work environment and work performance,

\section{Method}

This study uses a quantitative approach. The quantitative approach is based on the assumption that all the symptoms observed can be measured in the form of numbers so that it is possible to use synthetic analysis techniques (Sugiyono, 2006: 45). The method used in this study is descriptive method with linear regression techniques. Linear regression technique is research that describes the contribution / influence that exists between two or more variables. This study uses four variables, namely the principal's leadership variable $\left(\mathrm{X}_{\mathrm{I}}\right)$, work motivation $\left(\mathrm{X}_{2}\right)$ and work environment $\left(\mathrm{X}_{3}\right)$ as independent variables and teacher's work performance $(\mathrm{Y})$ as the dependent variable.

Population and Sample

Population

Population is the whole group of people, events or things of interest that the investigation wants to study (Sekaran, 2006: I23). According to Arikunto (2010: I73), the population is the whole subject of research. The population for this study were all Public Elementary School teachers in Alalak cluster in I40 North Banjarmasin sub-districts in IO schools in the Alalak cluster.

Sample

The sample is a part of the population that is deliberately chosen by the researcher to be observed, so that the sample size is smaller than the population and functions as a representative of the population (Nurhayati, 20I2: 36). What is learned from the sample, the conclusions can be applied to the population. For this reason, samples taken from the population must be truly representative. Questioning the number of samples follows the formula of Taro Yamame (Riduwan, 2008) as follows:

$$
\begin{aligned}
& \mathrm{N} \\
& \mathrm{n}= \\
& \mathrm{Nd}^{2}+1 \\
& \mathrm{n} \quad=\text { Minimum number of samples } \\
& \mathrm{N} \quad=\text { Total Population } \\
& \mathrm{d}=\text { Precision set }
\end{aligned}
$$

According to the results of the calculation of the formula obtained the number of samples is precision $0.05 \%$, then the minimum number of samples needed in measuring the leadership of the principal, work motivation, work environment and work performance of the teacher in this study are as many as:

140

$$
\begin{aligned}
& \mathrm{n}=\frac{}{140(0,05)^{2}+1} \\
& \mathrm{~N}=\mathrm{I} 03,7037037 \\
& \text { rounded to } \mathrm{I} 04
\end{aligned}
$$

The sample for this study were all Public Elementary School teachers in Alalak cluster in North Banjarmasin Districts, I04 teachers. In determining the method of selection in this study using simple random 
sampling. Simple random sampling is sampling taken randomly regardless of the strata that exist in the population by using the excel formula to make it faster and easier to dig data.

\section{Data Collection}

The data collection method in this study is to use a questionnaire. Principal's leadership questionnaire as many as 40 items, questionnaire work motivation as many as 36 items, teacher's work environment questionnaire as many as 17 items and questionnaire teacher's work achievement as many as 25 items.

\section{Data Analysis}

Trial Research Instrument

The instruments used are questionnaires through: a. Validity test

The collected data was analyzed by using SPSS 20 and Excel program tools by measuring valid data with the product moment formula.

b. Reliability Test

The reliability test was carried out with the SPSS 20 program aid with the Cronbach Alpha method greater than 0.6

Testing The Requirements For Hypothesis Analysis

a. Normality test

Test the normality of the data in the study using the Kolmogorov-Smirnov test with the help of SPSS version 20

b. Linearity Test

One other important assumption in a regression is the assumption of linearity. This assumption states that the relationship between one dependent variable

\section{Results and Discussion}

a. Characteristics Ofrespondents

a sample of around $33.65 \%$ of respondents were male, and around $66.35 \%$ of respondents were female, and the independent variable should be linear. Linear here can be interpreted as a relationship that is positive or negative by proving that from XI to $\mathrm{Y}$ the value of Sig $0,000<0,05$, as well as $\mathrm{X} 2$ to $\mathrm{Y}$ for the value of Sig $0,000<0,05$ and $\mathrm{X} 3$ against $\mathrm{Y}$ Sig value $0,000<$ 0,05 then these variables are said to be linear.

c. Homogeneity Test

The basis of decision making in the homogeneity test is (I) If the sig value $>0.05$ the conclusion is that homogeneity does not occur. (2) If the value of sig $<$ 0.05 , the conclusion is that homogeneity occurs

d. Multicollinearity Test

This multicollinearity test can be seen from the value of the variance inflation factor (VIF). Between independent variables to be said multicollinearity if the tolerance $<$ 0.I and VIF > IO, can be seen in SPSS output, tolerance value of each independent variable $>$ O.I and VIF value < IO, so it can be concluded that the regression model does not contain multicollinearity

Hypothesis Testing

Simple Regression Test

(a) Contributions between Principal Leadership and Teacher's Work Achievement, (b) Contributions between Work Motivation and Teacher's Work Achievement, (c) Contributions between Work Environment and Teacher's Work Achievement

\section{Multiple linear regression}

This analysis is used to determine the contribution of principals' leadership, work motivation and work environment (XI, X2 and X3) to teacher work performance $(Y)$ with multiple regression cases. It is expected that more relevant data will be used indicating that there were more female respondents than male respondents.

9.2 Contribution Of Principal Leadership, Motivation And Work Environment To Teachers Achievement

Table I Multiple Regressioncases

\begin{tabular}{|c|c|c|c|c|c|c|}
\hline \multirow{2}{*}{\multicolumn{2}{|c|}{ Model }} & \multicolumn{4}{|c|}{ Coefficients $^{a}$} & \multirow{3}{*}{ Sig. } \\
\hline & & \multicolumn{2}{|c|}{ Unstandardized Coefficients } & Standardized & \multirow{2}{*}{$\mathrm{T}$} & \\
\hline & & B & Std. Error & Beta & & \\
\hline \multirow{4}{*}{ I } & (Constant) & 15,390 & $5,5 \mathrm{I} 3$ & & $2,79 \mathrm{I}$ & ,006 \\
\hline & X3 & ,374 & ,II2 & 295 & 3,355 & ,OOI \\
\hline & $\mathrm{X} 2$ & ,2I3 & ,065 & ,324 & 3,255 & ,002 \\
\hline & $\mathrm{XI}$ & ,II9 & ,050 & ,218 & 2,369 & ,020 \\
\hline
\end{tabular}

a. Dependent Variable: Y 
from table 3.II, the tolerance value of each variablefree $>$ O.I and VIF value $<$ IO, so it can be concluded that the model and regression does not contain multicollinearity.

Table 2 Coefficient of Determination XI, X2 and X3 to Y

Model Summary

\begin{tabular}{ccccc}
\hline Model & $\mathrm{R}$ & R Square & Adjusted R Square & Std. Error of the Estimate \\
\hline $\mathrm{I}$ &, $707^{\mathrm{a}}$ &, 500 &, 485 & 5,97276 \\
\hline
\end{tabular}

a. Predictors: (Constant), XI, X3, X2

b. Dependent Variable: Y

From the table above, the determination coefficient is calculated by squaring the Correlation Coefficient (R) $=0.707$, then the coefficient of determination value $(\mathrm{R}$ square $)=0.707 \times 0.707=0.500$ or $50 \%$. It means that the ability of independent variables together in explaining the variance of the dependent variable is $50 \%$. Based on these interpretations, it appears that the value of $\mathrm{R}$ Square is a fairly strong contribution. Where the value is obtained so that $\mathrm{H}_{0}$ is rejected which means that together there is a significant contribution of the independent variable (principal leadership, motivation and teacher work environment) to the dependent variable (teacher learning achievement) Elementary schools in Alalak Cluster, North Banjarmasin Subdistrict, thus the hypothesis this is accepted.

Principal's leadership will be accepted by teachers ifapplied leadership is very suitable and liked by his teachers.So if it's like that the teacher will have a tendency toimprove work performance. Good principal's leadershipis the principal's leadership that can utilize resourcesespecially human resources namely the teacher, then in turn willimprove teacher work performance with good results.

\section{Conclusion}

From the results of the hypothesis test showing the leadership of the principal, the teacher's work motivation and the teacher's work environment together contribute to the teacher's work performance by $50 \%$ with the value of $\mathrm{R}$ Square quite strong and the value is reached so that Ho is rejected, thus this hypothesis is accepted.

\section{References}

Arikunto, Suharsimi. 2010. Prosedur Penelitian Suatu Pendekatan Praktik. Jakarta: PT. Remaja Rosdakarya

Bambang, Kusriyanto. 2000. Meningkatkan Produktivitas Karyawan. Jakarta: PT. Pustaka Binaman Pressindo

Malayu S.P. Hasibuan, 2008. Manajemen Sumber Daya Manusia. Jakarta, Bumi Aksara

Mardiana. 2005. Manajemen Produksi. Jakarta: IPWI

Munir, Abdullah. 2008. Menjadi Kepala Sekolah Efektif. Yogyakarta: Ar-Ruzz Media

Nurhayati, Siti. 2012. Metode Penelitian Praktis (edisi ke-2). Pekalongan: Usaha Nasional

Robbins, S.P dan Judge. 2007. Perilaku Organisasi. Jakarta: Salemba Empat.

Riduwan. 2008. Dasar-dasar Statistika. Bandung: Alfabeta.

Sekaran, U. 2006. Metodologi Penelitian. Jakarta: Salemba Empat

Simanjuntak, Burhan. 2003. Perilaku Organisasi. Yogyakarta: Remaja Rosdakarya.

Sugiyono. 2006. Metode Penelitian Pendidikan. Bandung: Alfabeta

Wibowo. 2010. Manajemen Kinerja, Edisi Ketiga. Jakarta: Rajawali Press 